\title{
MIEJSCE I ROLA LUDZI STARSZYCH W RODZINIE W NAUCZANIU PAPIESKIM W XXI WIEKU
}

WXXI wieku nauczanie papieży Franciszka, Benedykta XVI i Jana Pawła II, ukazując rolę i miejsce osób starszych w rodzinie, przywraca im szacunek. Papieże chca, by osoby w podesztym wieku byty szanowane i z właściwa uwaga otoczone troska. Papieże udowadniaja, że ludzie starsi sa nie tylko beneficjentami, lecz także dawcami w rodzinie. Dlatego seniorzy stanowia cenne oparcie dla młodszych pokoleń, ponieważ niosa madrość i doświadczenie życiowe, historię rodziny i narodu, a także sa świadkami wiary. Według wymienionych wyżej papieży, w przeszłości szacunek wobec osób starszych byt pewnego rodzaju czynnikiem warunkującym humanizm. Niewatpliwie tak również powinno być i teraz, aby pozytywnie świadczyć o jakości cywilizacji XXI wieku.

Stowa kluczowe: osoby starsze, rodzina, papieże: Jan Pawet II, Benedykt XVI, Franciszek.

\section{Wprowadzenie}

Nauczanie Kościoła Katolickiego na temat godności osób starszych jest głęboko zakorzenione w Piśmie Świętym. Bazując na tekstach biblijnych starano się chronić tę godność, miedzy innymi poprzez ukazywanie roli społecznej seniorów i potrzebę zabezpieczania ich życia na płaszczyźnie psychofizycznej i duchowej'

* Ks. Roman Ceglarek - kapłan archidiecezji częstochowskiej, dr teologii, wykładowca katechetyki w Wyższym Instytucie Teologicznym w Częstochowie oraz w Wyższym Seminarium Duchownym Archidiecezji Częstochowskiej i Wyższym Seminarium Duchownym Diecezji Sosnowieckiej w Częstochowie, członek Stowarzyszenia Katechetyków Polskich i Wieluńskiego Towarzystwa Naukowego.

1 Zob. N. Pikuła, Etos starości w aspekcie społecznym. Gerontologia dla pracowników socjalnych, Kraków 2011. 
W XX wieku problematyka była szczególnie widoczna w wypowiedziach Jana Pawła II ${ }^{2}$. Trzeba także nadmienić, że za jego pontyfikatu, dokładnie 1.10.1989 r., Papieska Rada ds. Świeckich wydała specjalny dokument zatytułowany Godność i posłannictwo ludzi starszych w Kościele i świecie ${ }^{3}$, poświęcony w całości osobom w podeszłym wieku. Kwestia ta jest nadal żywa w myśli Kościoła Katolickiego. Wystarczy wspomnieć chociażby ostatni synod biskupów, który temat osób starszych wpisał w szeroki kontekst zagadnień związanych z kondycją współczesnej rodziny. Zwrócił uwagę na fakt, że każdy z jej członków jest ważny i wezwany

2 Jan Paweł II, Adhortacja apostolska Familiaris consortio, Watykan 1981, tenże, Encyklika Laborem exercens o pracy ludzkiej, Watykan 1981; tenże, $W$ doświadczeniach starości łączcie się z Chrystusem na krzyżu. Spotkanie z ludźmi starymi w katedrze w Monachium, w: Nauczanie papieskie, red. E. Weron, A. Jaroch, t. 3, cz. 2, PoznańWarszawa 1986, s. 699-704; tenże, Skierujmy nasze myśli ku najstarszym, w: Nauczanie papieskie, red. E. Weron, A. Jaroch, t. 1, Poznań-Warszawa 1987, s. 210-211; tenże, Posynodalna adhortacja apostolska Christifideles laici o powołaniu i misji świeckich w Kościele i świecie dwadzieścia lat po Soborze Watykańskim II, Watykan 1988; tenże, Pochylmy głowy przed ludźmi starymi. Anioł Pański, w: Nauczanie papieskie, red. E. Weron, A. Jaroch, t. 5, cz. 1, Poznań 1993, s. 9; tenże, Chrześcijański sens cierpienia i starości. W szpitalu św. Karola Boromeusza w Onitsha, w: Nauczanie papieskie, t. 5, cz. 1, dz. cyt., s. 186-187; tenże, Szczególna misja starszych w życiu rodziny ludzkiej. Do uczestników międzynarodowego forum poświęconego aktywności ludzi starych, w: Nauczanie papieskie, t. 3, cz. 2, dz. cyt., s. 291-293; tenże, Poparcie roli osób starszych w rodzinie i społeczeństwie, w: Nauczanie papieskie, t. 5, cz. 1, dz. cyt., s. 612-614; tenże, Środki przekazu społecznego a problem ludzi starszych. Orędzie na Światowy Dzień Środków Przekazu Społecznego, w: Nauczanie papieskie, t. 5, cz. 1, dz. cyt., s. 668-671; tenże, Wielkość cywilizacji mierzy się postawa wobec osób starszych. Przemówienie do Ruchu Emerytów i Starców, w: Nauczanie papieskie, t. 5, cz. 1, dz. cyt., s. 774-776; tenże, Cenna rola osób starszych w Kościele, „L'Osservatore Romano” (wydanie polskie) [dalej: L'ORpol] 1994, nr 11, s. 38-39; tenże, Encyklika Evangelium vitae o wartości i nienaruszalności życia ludzkiego, Watykan 1995; tenże, Orędzie do światowego zebrania poświęconego sprawie starzenia się ludności, w: Nauczanie papieskie, red. E. Weron, A. Jaroch, t. 5, cz. 2, Poznań 1996, s. 222-226; tenże, Starzec nich będzie biegunem ukierunkowania dla młodych pokoleń. Do starców z diecezji rzymskiej, w: Nauczanie papieskie, t. 5, cz. 2, dz. cyt., s. 961-963; tenże, List do osób w podeszłym wieku [dalej: LdS], L'OR 1999, nr 12, s. 4-11; tenże, Nie dajcie się zwyciężać złu, ale zło dobrem zwyciężajcie. Spotkanie czterech pokoleń na stadionie Azteków, L'ORpol 1999, nr 4, s. 27-29.

3 Papieska Rada ds. Świeckich, Godność i posłannictwo ludzi starszych w Kościele i świecie, w: W trosce o życie, dz. cyt., s. 499-516. 
do podjęcia dzieła ewangelizacji, $\mathrm{w}$ tym także starsi ${ }^{4}$. Ale nie tylko podczas obrad synodalnych podejmowano problematykę osób starszych w rodzinie. Przewija się ona w nauczaniu trzech ostatnich papieży: Jana Pawła II, Benedykta XVI i Franciszka. Warto prześledzić ich wypowiedzi, by zobaczyć: jak określają oni miejsce i rolę ludzi starszych w rodzinie w XXI wieku.

\section{Ludzie starsi bogactwem rodziny}

Wszyscy papieże podkreślają fakt, że rodzina jest pierwszym i najważniejszym środowiskiem wychowawczym. Nie ma innego, od którego zależałoby więcej, niż od rodziny. Mając tę świadomość, zaznaczają w swych wypowiedziach, że jest ona równocześnie głównym środowiskiem wychowania religijnego, zwłaszcza w początkowym okresie życia. Pierwszoplanową rolę w tym zakresie odgrywają rodzice, co jest ich obowiązkiem, ale także prawem, które wynika zarówno z natury, jak i z istoty sakramentu małżeństwa. Jednak nie są jedynymi, którzy odpowiadają za wychowanie dzieci, w tym za wychowanie do wiary. Te działania winny być wspierane przez pozostałych członków rodziny, między innymi przez babcie i dziadków. Osoby starsze, zdaniem papieży, wnoszą bowiem istotny wkład w rozwój dzieci, kształtowanie osobowości, hierarchii wartości czy stylu życia. $\mathrm{Z}$ tej racji widzą ich obecność w rodzinie jako wyjątkowo cenną i mającą realny wpływ na rozwój psychofizyczny i religijny dzieci. Nie dziwi więc fakt, że papieże przypominają o tym w swoich wypowiedziach. Warto wspomnieć chociażby słowa Benedykta XVI wypowiedziane do uczestników XVIII Zgromadzenia Plenarnego Papieskiej Rady ds. Rodziny. Powiedział wtedy o osobach starszych w rodzinach, że są ,,skarbem, którego nie możemy odebrać nowym pokoleniom, zwłaszcza ich świadectwa wiary"5. Tę myśl jeszcze mocniej wyartykułował w adhortacji Aficae Munus stwierdzając, że: „Są oni skarbem dla wszystkich części składowych rodziny, zwłaszcza dla młodych małżeństw i dzieci, które znajdują u nich zrozumienie i miłość. Nie tylko przekazali oni życie, lecz przyczyniają się swoją postawą do umocnienia rodziny (por. Tt 2, 2-5), a poprzez swoje modlitwy i życie wiarą, duchowo wzbogacają wszystkich członków swojej rodziny i wspólnoty”6. Wyraził to

4 „Relatio synodi” - Wezwania duszpasterskie zwiąane z rodzina $w$ kontekście ewangelizacji, L'ORpol 2014, nr 11, s. 8-18.

5 Benedykt XVI, Dziadkowie sa cennym skarbem każdej rodziny. Przemówienie do uczestników XVIII Zgromadzenia Plenarnego Papieskiej Rady ds. Rodziny, L'ORpol 2008, nr 5, s. 28.

6 Benedykt XVI, Posynodalna adhortacja apostolska Africae Munus [dalej: AM], Watykan 2011, nr 48. 
samo Franciszek w swoim przesłaniu z okazji dwudziestolecia Papieskiej Akademii „Pro Vita”. Pisząc o roli ludzi starszych w rodzinie, wyraźnie zaznaczył, że czyni to „dla potwierdzenia znaczenia osoby w podeszłym wieku jako podmiotu wspólnoty, która ma swoją misję do wypełnienia (...)"’. Także Jan Paweł II podejmował tę problematykę. Zachęcał, by rozwijano w opinii publicznej świadomość, że ludzie starsi są bogactwem, które należy doceniać, zwłaszcza w rodzinie. Jego zdaniem ich obecność we wspólnocie rodzinnej przyczynia się do jej dobrobytu, nieraz materialnego, ale przede wszystkim duchowego, i sprawia, że staje się ona szkołą humanizacji człowieka ${ }^{8}$.

\section{Afirmacja godności czlowieka starszego w rodzinie}

Dowartościowując obecność osób starszych we wspólnocie rodzinnej, papieże wzywają pozostałych członków rodziny do otoczenia babć i dziadków należnym szacunkiem. Za jego fundament uważają czwarte przykazanie, twierdząc, że jest ono źródłem miłości dzieci do rodziców i podstawą silnych więzi między pokoleniami. Sporo na ten temat pisał Jan Paweł II, zwłaszcza w Liście do osób w podesztym wieku (LdS 11). Powstał on jednak pod koniec XX wieku, a więc w okresie wykraczającym poza ramy czasowe niniejszej publikacji. W XXI wieku papieże Benedykt XVI i Franciszek podjęli to zagadnienie lokując szacunek do dziadków - podobnie jak Jan Paweł II - właśnie w kontekście Dekalogu. Zauważyli, że czwarte przykazanie winno być odczytywane w szerszym wymiarze, a więc nie tylko w odniesieniu do rodziców, ale także do osób starszych, którym należy się w rodzinie taka sama cześć, jak matce i ojcu. Na kanwie tego przykazania Benedykt XVI stwierdza, że: „Bóg pragnie, aby godność, wartość, zdrowie i dobrobyt osób starszych były należycie szanowane, a Kościół poprzez swoje instytucje charytatywne (...) stara się wypełniać przykazanie Pana, ukazując szanowanie życia bez względu na wiek czy stan zdrowia"9. Obaj papieże przypominają w swoim nauczaniu, że taka postawa - zgodnie z przesłaniem tekstów biblijnych - może

7 Franciszek, Najcięższa choroba, na jaka są narażone osoby starsze, jest opuszczenie. Przesłanie z okazji 20-lecia Papieskiej Akademii „Pro Vita”, L'ORpol 2014, nr 3-4, s. 21.

8 Jan Paweł II, Dar dtugiego życia. Jubileusz Ludzi Starych, L'ORpol 2000, nr 11-12, s. 14; tenże, Ludzie starsi w życiu spoleczeństwa. List papieski do uczestników II Światowego Zgromadzenia poświęconego problemom starzenia się ludności, L'ORpol 2002, nr 6, s. 8-9; tenże, Bo tu jest twoje życie i dtugie trwanie twego pobytu na ziemi. Orędzie Ojca Świętego na Wielki Post 2005 r., L'ORpol 2005, nr 3, s. 6.

9 Benedykt XVI, Każdy z nas jest kochany i niezbędny. Wizyta w Domu św. Piotra w Londynie, L'ORpol 2010, nr 11, s. 35. 
być wynagrodzona przez Boga błogosławieństwami, jeśli tylko będzie właściwie wypełniona ${ }^{10}$.

Analizując wypowiedzi trzech ostatnich papieży, można dojść do wniosku, że ów szacunek do osób starszych w rodzinie czy też poza nią powinien przejawiać się w modlitwie za nich oraz w działaniach zabezpieczających ich godne życie, byt materialny, właściwą opiekę medyczną, gwarantujących im aktywność społeczną, sięgających po ich doświadczenie zawodowe i fachową wiedzę, czy umożliwiających im podjęcie różnych form apostolatu. Wszyscy zgodnie twierdzą, że sposób, w jaki osoby starsze są otaczane opieką, świadczy o jakości rodziny, społeczeństwa, a nawet cywilizacji ${ }^{11}$.

W te działania, mające na celu otoczenie osób starszych należną estymą, wpisuje się także kształtowanie świadomości społecznej, która powinna całkowicie wykluczyć eutanazję jako akt z natury zły, będący poważnym naruszeniem prawa Bożego i obrazą godności człowieka, a promować ochronę życia każdego człowieka od poczęcia aż do naturalnej śmierci ${ }^{12}$. Oczywiście każdy z papieży piętnował

10 Tamże; Franciszek, Ewangelia spotkania młodych i starszych. Homilia podczas Mszy św. dla ludzi w podeszłym wieku, L'ORpol 2014, nr 10, s. 40.

$11 \quad$ Jan Paweł II, Ludzie starsi w życiu społeczeństwa. List papieski do uczestników II Światowego Zgromadzenia poświęconego problemom starzenia się ludzi, L'ORpol 2002, nr 6, s. 8-9; tenże, Bo tu jest twoje życie i dtugie trwanie twego pobytu na ziemi. Orędzie na Wielki Post 2005 r., L'ORpol 2005, nr 3, s. 6; Benedykt XVI, Do pensjonariuszy rzymskiego domu spokojnej starości: ludzie w podeszłym wieku sa cenni dla społeczeństwa i Kościoła, w: http://pl.radiovaticana.va/storico/2012/11/12/benedykt_xvi_do_pensjonariuszy_rzymskiego_domu_spokojnej_starości/pol-638136 [dostęp: 5.01.2015], tenże, Chrześcijańska nauka o cierpieniu. Przemówienie do uczestników międzynarodowej konferencji Papieskiej Rady ds. Duszpasterstwa Stużby Zdrowia i Chorych, L'ORpol 2013, nr 1, s. 28-30; Franciszek, Miłość cierpliwa, która rodzi radość. Homilia Ojca Świętego podczas Mszy św. dla rodzin, L'ORpol 2013, nr 12, s. 12; tenże, W rodzinie uczymy się kochać i bronić życia. Audiencja dla uczestników zgromadzenia plenarnego Papieskiej Rady ds. Rodziny, L'ORpol 2013, nr 12, s. 27-29; tenże, „Busola” ludu Bożego. Przemówienie do członków Instytutu „Dignitatis humanae”, L'ORpol 2014, nr 1, s. 38; tenże, Prawdziwa rewolucja jest współczucie. Przemówienie do wspólnoty św. Idziego, L'ORpol 2014, nr 7, s. 19; tenże, Prośmy Maryję o opiekę nad osobami starszymi. Stowa przed modlitwa „Anioł Pański”, L'ORpol 2014, nr 10, s. 42; tenże, Adhortacja apostolska Evangelii gaudium o głoszeniu Ewangelii w dzisiejszym świecie [dalej: EG], Watykan 2013, nr 76, 210.

12 Jan Paweł II, Człowieka nie można sprowadzić do przedmiotu. List do Michaela Camdessusa, Prezesa Tygodni Społecznych Francji, w: W trosce o życie, dz. cyt., s. 183; tamże, Jan Paweł II, W obronie życia i zdrowia każdej osoby ludzkiej. Przemówienie do członków Papieskiej Akademii Pro Vita, s. 209, tenże, Medycyna a prawa człowieka. Przemówienie na Jubileusz Lekarzy Katolickich, w: W trosce o życie, dz. cyt., s. 257; tenże, 
eutanazję. Jan Paweł II i Benedykt XVI ukazywali ją jako przejaw cywilizacji śmierci. Wszyscy widzieli w niej zagrożenie dla osób starszych i przestrzegali przed pojmowaniem jej jako sposobu rozwiązywania niektórych trudnych sytuacji egzystencjalnych związanych ze starością, jako drogi samowyzwolenia z sytuacji, która z jakiegoś powodu stała się trudna do zniesienia. Omawiając kwestię eutanazji jako całkowitego wyeliminowania ze społeczeństwa, podejmowali także refleksję nad innymi formami marginalizacji ludzi w tym wieku. Papież Franciszek nazwał te procesy ukrytą eutanazją i określił je jako element kultury odrzucenia, która stała się piętnem współczesnej cywilizacji ${ }^{13}$. Problematykę tę podejmował w wielu swoich wypowiedziach ${ }^{14}$, między innymi w przesłaniu do uczestników zgromadzenia ogólnego Papieskiej Akademii „Pro Vita”, zwołanego z racji jej dwudziestolecia, pisał: „W istocie, w naszych społeczeństwach obserwuje się bezwzględne panowanie logiki ekonomicznej, która wyklucza, a niekiedy zabija, i której ofiarami pada dziś bardzo wielu ludzi, poczynając od osób w podeszłym wieku"15. I dodaje w swojej adhortacji Evangelii gaudium: „Daliśmy początek kulturze

Ochrona zdrowia a społeczeństwo. Przemówienie do uczestników Kongresu Papieskiej Rady ds. Duszpasterstwa Stużby Zdrowia, tamże, s. 265; tenże, Misja papieża jest obrona praw człowieka. Przemówienie z okazji uroczystości nadania doktoratu honoris causa Uniwersytetu La Sapienza, tamże, s. 282; tenże, Człowiek chory zawsze zachowuje swa godność. Przemówienie do uczestników Międzynarodowego Kongresu Lekarzy Katolickich, tamże, s. 296; tenże, Towarzyszyć choremu aż do końca. Przemówienie do uczestników konferencji Papieskiej Rady ds. Duszpasterstwa Stużby Zdrowia, tamże, s. 299-300; tenże, Chrystus przemienia cierpienie w źródło łaski i życia. Orędzie na XI Światowy Dzień Chorego 11.02.2003 r., tamże, s. 398; Benedykt XVI, Bóg darzy miłościa człowieka od chwili poczęcia. Przemówienie do uczestników kongresu Papieskiej Akademii Pro Vita, w: W trosce o życie, dz. cyt., s. 307-308; tenże, Żaden człowiek nie powinien umierać w samotności. Przemówienie do uczestników zgromadzenia ogólnego Papieskiej Akademii Pro Vita i zorganizowanego przez nią kongresu, tamże, s. 334.

13 Franciszek, Prawdziwa rewolucja jest współczucie, dz. cyt., s. 19; tenże, Trzeba budować porozumienie wychowawcze, L'ORpol 2014, nr 10, s. 24.

14 Franciszek, Nikogo nie wolno odrzucać. Wizyta $w$ faweli Varginha, L'ORpol 2013, nr 8-9, s. 6-7; tenże, Niech was będzie stychać. Spotkanie z młodzieża argentyńska, L'ORpo 2013, nr 8-9, s. 8; tenże, Skażeni przez kulturę odrzucenia, L'ORpol 2013, nr 8-9, s. 48-49; tenże, Bez pracy nie ma godności. Przemówienie podczas spotkania ze światem pracy na Largo Carlo Felice, L'ORol 2013, nr 11, s. 21; tenże, «Busola»ludu Bożego, dz. cyt., s. 38; tenże, Dzieci i dziadkowie sa nadzieją ludu. Przemówienie do członków włoskiego Ruchu na rzecz Życia, L'ORpol 2014, nr 5, s. 27.

15 Franciszek, Najcięższq choroba, na jaka sq narażone osoby starsze, jest opuszczenie, dz. cyt., s. 21. 
«odrzucenia», którą wprost się promuje. Nie chodzi już po prostu o zjawisko wyzysku i ucisku, ale o coś nowego: przez wykluczenie dotyka się samego korzenia przynależności do społeczeństwa, w którym człowiek żyje, jako że nie jest w nim na samym dole, na peryferiach, lub bez władzy, ale jest poza nim. Wykluczeni nie są «wyzyskiwani», ale są odrzuceni, są «niepotrzebnymi resztkami»»" (EG 53). Zdaniem papieża przejawem tego wykluczenia, tej ukrytej eutanazji wobec osób starszych, jest chociażby udzielanie im świadczeń socjalnych tylko na określony czas, ograniczanie czy nieraz nawet zaniechanie działań medycznych, porzucanie ich w sytuacji, gdy nie są już wydajni ekonomicznie, itp.

\section{Mądrość i doświadczenie atutem osób starszych w rodzinie}

Zdaniem papieży osobom starszym w rodzinie czy też w ogóle w społeczeństwie szacunek należy się również ze względu na ich olbrzymi zasób doświadczeń, a co za tym idzie ze względu na ich wiedzę, mądrość życiową oraz dojrzałość. Podkreślił to Jan Paweł II w Roku Jubileuszowym podczas spotkania z osobami starszymi i wezwał do wykorzystania ich potencjału. Mówił wtedy: ,Świętować ich Jubileusz znaczy przede wszystkim przyjąć orędzie Chrystusa skierowane do tych ludzi, a zarazem wzbogacić się doświadczeniem i mądrością, którymi oni mogą się dzielić na tym etapie swojego życia. Dla wielu z nich trzeci wiek to czas reorganizacji własnego życia i korzystania ze zdobytego doświadczenia i umiejętności"16. W podobnym duchu wypowiedział się papież Franciszek, dodając jednocześnie, że ów potencjał ludzi w podeszłym wieku powinien pomóc młodym lepiej oceniać aktualne wydarzenia i wyciągać właściwe wnioski, by nie powielać błędów, które były kiedyś ich udziałem. Słowa te zawarł we wspomnianej adhortacji Evangelii gaudium, pisząc: „Starsi wnoszą pamięć i mądrość doświadczenia, która zachęca, by głupio nie powtarzać tych samych błędów z przeszłości” (EG 108). Wracał do tego w licznych przemówieniach, prosząc młodzież o uszanowanie mądrości poprzednich pokoleń, o bazowanie na ich doświadczeniach, a także o słuchanie życiowych rad babć i dziadków ${ }^{17}$.

W ten nurt wpisują się również słowa Benedykta XVI skierowane do starszych podopiecznych Domu św. Piotra w Londynie: „Każde pokolenie może się wiele

16 Jan Paweł II, Dar dtugiego życia, dz. cyt., s. 14.

17 Franciszek, Każdego dnia budujemy pokój w rodzinie. Rozważanie Papieża podczas spotkania modlitewnego z rodzinami, L'ORpol 2013, nr 12, s. 12; tenże, Młodzi musza mieć skrzydła i korzenie. Wideokonferencja z uczniami z pięciu krajów świata, L'ORpol 2014, nr 10, s. 25; tenże, Ewangelia spotkania młodych i starszych, dz. cyt., s. 40. 
nauczyć, korzystając z doświadczeń i mądrości pokolenia, które je poprzedziło"18. Zdaniem papieża te przymioty, które z biegiem lat młodzi ludzie będą dopiero nabywać, a które posiadają starsi, powinny być wykorzystane do przezwyciężania podziałów w rodzinie, pogłębiania więzi między jej członkami, ale także do budowania społeczeństwa bardziej sprawiedliwego i solidarnego oraz do inicjowania i wspomagania działań pojednawczych wśród domowników między różnymi wspólnotami (AM 48, 49). W ten sposób osoby starsze - posiadające autorytet będący owocem doświadczenia i kompetencji zdobytych dzięki konsekwentnemu życiu i osobistemu zaangażowaniu - winny stawać się wychowawcami młodszych członków rodziny, którzy z tych przymiotów powinni czerpać realizując swoje życiowe powołanie ${ }^{19}$.

\section{Ludzie starsi strażnikami przeszłości w rodzinie}

Ludzie starsi stanowią wielką wartość także ze względu na rolę, jaką pełnią $\mathrm{w}$ rodzinie $\mathrm{w}$ procesie budowania tożsamości społeczno-kulturowej i narodowej. Dzieje się tak chociażby przez przekazywanie pamięci narodowej, tradycji patriotycznych, dobrych obyczajów czy cennych wartości. Zwrócił na to uwagę papież Franciszek w kilku swoich przemówieniach ${ }^{20}$, między innymi podczas pielgrzymki do Argentyny. Powiedział wtedy: „Ludzi starszych (...) proszę z całego serca: nie przestawajcie być bogactwem kulturowym naszego narodu, bogactwem przekazującym sprawiedliwość, historię, wartości, przekazującym pamięć narodu"21. Starsi są więc ważnymi świadkami przeszłości, osobami które mogą kształtować tożsamość narodową, przekazywać miłość do ojczyzny, rozwijać świadomość własnego miejsca w społeczeństwie, wskazywać na pewne zasady i wartości będące punktem odniesienia dla młodego pokolenia. Stają się zatem strażnikami pamięci zbiorowej posiadającymi mądrość i bezcenne dziedzictwo ludzkie i duchowe, które powinni przekazywać kolejnym pokoleniom. A to oznacza, że wykluczenie ich z rodziny czy społeczeństwa byłoby odrzuceniem pamięci o przeszłości, w której przecież zakorzeniona jest przyszłość.

18 Benedykt XVI, Każdy z nas jest kochany i niezbędny, dz. cyt., s. 35.

19 Por. Benedykt XVI, List do diecezji rzymskiej o pilnej potrzebie wychowania, L'ORpol 2008, nr 4, s. 5.

20 Franciszek, $W$ rodzinie uczymy się kochać i bronić życia, dz. cyt., s. 28; tenże, Równość w zróżnicowaniu. Przesłanie wideo do uczestników III Festiwalu Nauki Społecznej Kościoła, L'ORpol 2014, nr 1, s. 29; tenże, Dzieci i dziadkowie sa nadzieją ludu, dz. cyt., s. 28; tenże, Prawdziwą rewolucja jest wspótczucie, dz. cyt., s. 19.

${ }^{21}$ Franciszek, Niech was będzie stychać, dz. cyt., s. 8. 
Podkreślił to Franciszek, chociażby w przemówieniu do katolików włoskich w czasie obchodów 47. Tygodnia Społecznego, mówiąc: „Nadzieja i przyszłość zakładają pamięć. Pamięć osób starszych naszego społeczeństwa jest wsparciem w postępowaniu naprzód. Przyszłość społeczeństwa, (...) jest zakorzeniona w ludziach starszych i w młodzieży - tej ostatniej, ponieważ ma siłę i wiek, pozwalające budować historię; w tamtych, ponieważ są żywą pamięcią. Lud, który nie troszczy się o osoby starsze i o dzieci oraz młodzież, nie ma przyszłości, ponieważ niszczy pamięć i obietnicę"22. W tym duchu wypowiadał się jeszcze kilkakrotnie, zwracając uwagę na fakt, że naród, który nie troszczy się o dziadków i nie traktuje ich z należnym szacunkiem, nie ma przyszłości, traci bowiem pamięć i odcina się od swoich korzeni, zatraca w ten sposób swoją tożsamość narodową i kulturową ${ }^{23}$. Podobnie wypowiadali się Jan Paweł II i Benedykt XVI. Ten pierwszy przypominał, iż człowiek powinien mieć świadomość, że żyje dziedzictwem tych, którzy go poprzedzili, a jego przyszłość w decydującej mierze zależy od tego, w jaki sposób zostały mu przekazane wartości kultury narodu, w którym wzrasta. Ponadto winien wiedzieć, że mądrość i doświadczenie osób starszych mogą być dla niego oświeceniem na drodze postępu ku coraz pełniejszej formie cywilizacji ${ }^{24}$. Z kolei ten drugi odniósł tę prawdę do rodziny, pokazując, iż babcie i dziadkowie są strażnikami jej przeszłości. Oni bowiem opowiadając wnukom przeszłość małżeńsko-rodzinną, tworzą dzieje rodziny i ideologię małżeńską. W ten sposób wprowadzają ich w historię rodziny, co przyczynia się do tworzenia ich fundamentów tożsamości rodzinnej, narodowej czy religijnej².

\section{Ludzie w podeszłym wieku świadkami wiary w rodzinie}

Mówiąc o wartości osób starszych w rodzinie, a także w społeczeństwie, nie można pominąć ich roli w przekazywaniu wiary. Generalnie rzecz ujmując, powinny to być działania wspomagające, bowiem pierwszymi wychowawcami i katechetami winni być rodzice, o czym wspomniano już wyżej. Zachodzące jednak

22 Franciszek, Solidarność między pokoleniami. Przesłanie z okazji 47. Tygodnia Społecznego Katolików Włoskich, L'ORpol 2013, nr 11, s. 33.

23 Franciszek, Każdego dnia odbudowujmy pokój $w$ rodzinie. Rozważanie Papieża podczas spotkania modlitewnego z rodzinami, L'ORpol 2013, nr 12, s. 12; tenże, Pamięć o przeszłości i przyszłości. Przemówienie podczas spotkania z ludźmi starszymi na placu św. Piotra, L'ORpol 2014, nr 10, s. 40; tenże, Równość w zróżnicowaniu, dz. cyt., s. 29.

24 Jan Paweł II, Bo tu jest twoje życie i długie trwanie twego pobytu na ziemi, dz. cyt., s. 6 .

25 Benedykt XVI, Dziadkowie sa cennym skarbem każdej rodziny, dz. cyt., s. 28-30. 
zmiany społeczno-ekonomiczne wymuszają nieraz na nich cedowanie tych zadań na babcie i dziadków. Główną przyczyną staje się emigracja zarobkowa. Jej efektem jest to, że pozostawione przez rodziców dzieci przechodzą pod bezpośrednią opiekę dziadków, którzy biorą na siebie trud wychowania, w tym także wychowania religijnego. Papież Franciszek te działania związane z przekazem wiary traktuje nie jako przywilej, ale właściwie jako ich obowiązek względem młodszego pokolenia. $\mathrm{Z}$ tej racji mówił do nich: „(...) nie jesteście tylko adresatami głoszenia ewangelicznego przesłania, ale zawsze jesteście także pełnoprawnymi ewangelizatorami, na mocy waszego chrztu. Każdy swój dzień możecie przeżywać jako świadkowie Pana w waszych rodzinach, w parafiach i innych środowiskach, w jakich bywacie, umożliwiając poznanie Chrystusa i Jego Ewangelii, zwłaszcza najmłodszym"26.

Jak niezwykle cenna jest ich rola w tym zakresie, niech świadczy osobiste świadectwo papieża Franciszka, który 18.05.2013 r. podczas czuwania modlitewnego z okazji dnia ruchów, nowych wspólnot i stowarzyszeń kościelnych powiedział: „Miałem tę łaskę, że wyrosłem w rodzinie, w której wiarą żyło się w sposób prosty i konkretny; ale to przede wszystkim moja babcia, mama mojego ojca, miała wielki wpływ na moją drogę wiary. Była to kobieta, która nam wszystko tłumaczyła, mówiła nam o Jezusie, uczyła nas katechizmu, (...) zabierała nas na procesję ze świecami. Po raz pierwszy usłyszałem przesłanie chrześcijańskie właśnie od tej kobiety, od mojej babci! (...). Pierwszy przekaz w domu, w rodzinie! Dlatego myślę o miłości (...) tak licznych babć, wkładanej w przekazywanie wiary. To one przekazują wiarę"27. Już z tych słów jasno wynika, że ten przekaz wiary następuje poprzez osobiste świadectwo ludzi starszych w rodzinie i związany jest między innymi z nauczaniem katechizmu, a co za tym idzie także z nauką różnych modlitw oraz z wpajaniem pobożnych praktyk poprzez wprowadzanie w życie liturgiczne i wspólnotowe Kościoła. Papież zauważa, że osobisty przykład osób starszych w sprawach wiary i moralności nie tylko inicjuje wiarę w życiu wnuków, ale również pokazuje, że mimo zmieniających się kontekstów społeczno-kulturowych i politycznych, a nawet mimo prześladowań, można wchodzić w dorosłość, zachowując

26 Franciszek, Przestrzenie godności i wolności. Spotkanie z uczestnikami międzynarodowej konferencji Papieskiej Rady ds. Duszpasterstwa Stużby Zdrowia i Chorych, L'ORpol 2014, nr 1, s. 30-31.

27 Franciszek, Kościół wychodzi naprzeciw wszystkim. Czuwanie modlitewne z okazji dnia ruchów, nowych wspólnot i stowarzyszeń kościelnych, L’ORpol 2013, nr 7, s. 16. 
wiarę i trwałą więź z Bogiem ${ }^{28}$. Franciszek nazywa ich strażnikami i gwarantami wiary, którzy zachowują pamięć Kościoła i przekazują ją młodym pokoleniom ${ }^{29}$.

O potrzebie autentycznych świadków wiary, ze wskazaniem na ludzi starszych, mówią także pozostali papieże. Podkreślał to zarówno Jan Paweł II, jak i Benedykt XVI. W tym kontekście stawiali im konkretne zadania, jakie mieli podejmować w rodzinie, parafii czy najbliższym otoczeniu. Jan Paweł II mówił między innymi: „Włączajcie się w głoszenie Ewangelii jako katechiści, animatorzy liturgii, świadkowie życia chrześcijańskiego. Poświęcajcie czas i energię modlitwie, czytaniu słowa Bożego i rozważaniu go"30. Z kolei Benedykt XVI zachęcał, by pomagali młodym ludziom w odkrywaniu znaczenia praktyk religijnych, świętowaniu niedzieli czy czytaniu słowa Bożego ${ }^{31}$. Jak widać, dla obu papieży w procesie religijnego wychowania w rodzinie bardzo ważna jest lektura Biblii. Benedykt XVI poświęcił temu zagadnieniu specjalną adhortację - Verbum Domini ${ }^{32}$. Podkreślił w niej znaczenie otwierania Biblii, rozważania i modlenia się nią. Dziadkowie mają w tym zakresie wielką misję do spełnienia. Powinni czytać swoim wnukom Pismo Święte, bowiem w ten sposób - jak mówi Benedykt XVI - przekazuje się dziecku swoją wiarę (VD 85). Dziecko posiada naturalną skłonność do medytacji, dlatego chętnie ogląda obrazy zawarte w Piśmie Świętym czy słucha opowiadań biblijnych, przez co niejako wnika w ten świat, utożsamia się z jej bohaterami, przyswaja ich przeżycia i postawy, poznaje historie biblijne, a wraz z nimi przyswaja sobie proste prawdy wiary. Wiedząc o tym, dziadkowie winni chętnie podejmować się

28 Franciszek, Głoście Ewangelię, jeśli trzeba, także słowami! Spotkanie z młodzieża na placu przed bazylika Matki Bożej Anielskiej, L'ORpol 2013, nr 11, s. 17; tenże, Naród odważny i silny. Audiencja generalna w Watykanie po podróży do Albanii, L'ORpol 2014, nr 10, s. 21.

29 Franciszek, List Papieża Franciszka do rodzin, L'ORpol 2014, nr 3-4, s. 23-24; tenże, Panie daj nam zaznać świętego upojenia. Dialog Papieża z kapłanami, młodzieża, rodzinami i osobami niepełnosprawnymi, L'ORpol 2014, nr 7, s. 28; tenże, Pamięć o przeszłości i przyszłości, dz. cyt., s. 39.

30 Jan Paweł II, Dar dtugiego życia, dz. cyt., s. 14.

31 Por. Benedykt XVI, Wychowanie do dobra jest możliwe również w naszych czasach. Przemówienie z okazji przekazania diecezji rzymskiej „Listu o pilnej potrzebie wychowania”, L'ORpol 2008, nr 4, s. 11; tenże, ,Tak” dla życia, ,tak” dla miłości i ,tak” dla pragnień obecnych $w$ sercach nas wszystkich. Spotkanie z biskupami - Waszyngton, L'ORpol 2008, nr 5, s. 43; tenże, Dziadkowie sa cennym skarbem każdej rodziny, dz. cyt., s. 28-30.

32 Por. Benedykt XVI, Adhortacja apostolska Verbum Domini o Słowie Bożym w życiu i misji Kościoła, Watykan 2010, nr 85 (dalej - VD). 
czytania, opowiadania i tłumaczenia wydarzeń biblijnych swoim wnukom, by w ten sposób pogłębiać ich wiarę ${ }^{33}$.

Warto jeszcze nadmienić, że o roli dziadków jako świadków wiary w rodzinie wspomina także Relatio synodi III Nadzwyczajnego Zgromadzenia Ogólnego Synodu Biskupów. Włącza ich w krąg odpowiedzialnych za formację religijną dzieci i młodzieży i widzi w nich sprzymierzeńców w dziele ewangelizacji rodziny i społeczeństwa ${ }^{34}$.

\section{Zakończenie}

Zmiany kulturowe dokonujące się w XXI wieku rzutują na sposób postrzegania osób starszych. Nierzadko dochodzi do ich marginalizacji i spychania na peryferia życia publicznego, zaniedbywania i dystansowania się od obowiązku zabezpieczenia ich zdrowia i życia. Problem ten został zauważony przez papieży Jana Pawła II, Benedykta XVI i Franciszka. W swoim nauczaniu podjęli oni temat osób starszych, by przywrócić im godność i dowartościować ich rolę i miejsce $\mathrm{w}$ rodzinie, a co za tym idzie także w społeczeństwie. W ich wypowiedziach wyraźnie widać, jak pragną kształtować świadomość wszystkich ludzi, nie tylko chrześcijan, w podchodzeniu do osób starszych. Chcą, by byli szanowani i otaczani należną troską. Przypominają, że człowiek ma do tego prawo na każdym etapie swojego życia. Oznacza to, że prawo to jest niezbywalne i przysługuje także ludziom starym u kresu ich egzystencji. Szczególnie odpowiedzialnymi za to czynią wszystkich członków rodziny, pokazując, że ludzie starzy są w niej nie tylko beneficjentami, ale również darczyńcami. Są oni bowiem cennym wsparciem dla młodych pokoleń, przekazują im mądrość i życiowe doświadczenie, historię rodziny i narodu, wreszcie stają się świadkami wiary, którzy podejmują w rodzinie trud wychowania religijnego i przekazu tradycji chrześcijańskiej. Zdaniem papieży szacunek do nich był w przeszłości pewnym wyznacznikiem humanizmu i poziomu człowieczeństwa. Niewątpliwie powinien takim zostać również i teraz, by pozytywnie świadczyć o jakości cywilizacji w XXI wieku.

33 Por. R. Ceglarek, Il compito dei genitori nell'annuncio della parola di Dio secondo l'esortazione apostolica «Verbum Domini» di Benedetto XVI, „Studia Pastoralne” 2013, nr 9, s. 275-276.

34 „Relatio synodi”, dz. cyt., s. 8-18. 


\section{Literatura}

Benedykt XVI, „Tak” dla życia, ,tak” dla miłości i ,tak” dla pragnień obecnych w sercach nas wszystkich. Spotkanie z biskupami - Waszyngton, L'ORpol 2008, nr 5, s. 41-45.

Benedykt XVI, Adhortacja apostolska Verbum Domini o Słowie Bożym w życiu i misji Kościoła, Watykan 2010.

Benedykt XVI, Bóg darzy miłościa człowieka od chwili poczęcia. Przemówienie do uczestników kongresu Papieskiej Akademii Pro Vita, w: W trosce o życie. Wybrane dokumenty Stolicy Apostolskiej, red. J. Brusiło, Tarnów 2012, s. 306-308.

Benedykt XVI, Chrześcijańska nauka o cierpieniu. Przemówienie do uczestników międzynarodowej konferencji Papieskiej Rady ds. Duszpasterstwa Stużby Zdrowia i Chorych, L'ORpol 2013, nr 1, s. 28-30.

Benedykt XVI, Do pensjonariuszy rzymskiego domu spokojnej starości: ludzie w podesztym wieku sa cenni dla społeczeństwa i Kościoła, w: http:// pl.radiovaticana.va/storico/2012/11/12/benedykt_xvi_do_pensjonariuszy_ rzymskiego_domu_spokojnej_starości/pol-638136.

Benedykt XVI, Dziadkowie sa cennym skarbem każdej rodziny. Przemówienie do uczestników XVIII Zgromadzenia Plenarnego Papieskiej Radyds. Rodziny, L'ORpol 2008, nr 5, s. 28-30.

Benedykt XVI, Każdy z nas jest kochany i niezbędny. Wizyta w Domu św. Piotra w Londynie, L'ORpol 2010, nr 11, s. 35-36.

Benedykt XVI, List do diecezji rzymskiej o pilnej potrzebie wychowania, L'ORpol 2008, nr 4, s. 4-6.

Benedykt XVI, Posynodalna adhortacja apostolska Africae Munus, Watykan 2011. Benedykt XVI, Wychowanie do dobra jest możliwe również w naszych czasach. Przemówienie z okazji przekazania diecezji rzymskiej ,Listu o pilnej potrzebie wychowania", L'ORpol 2008, nr 4, s. 10-12.

Benedykt XVI, Żaden człowiek nie powinien umierać w samotności. Przemówienie do uczestników zgromadzenia ogólnego Papieskiej Akademii Pro Vita i zorganizowanego przez nia kongresu, w: W trosce o życie. Wybrane dokumenty Stolicy Apostolskiej, red. J. Brusiło, Tarnów 2012, s. 332-334.

Ceglarek R., Il compito dei genitori nell'annuncio della parola di Dio secondo l'esortazione apostolica „Verbum Domini” di Benedetto XVI, „Studia Pastoralne" 2013, nr 9, s. 271-277.

Franciszek, ,,Busola” ludu Bożego. Przemówienie do członków Instytutu „Dignitatis humanae”, L'ORpol 2014, nr 1, s. 38. 
Franciszek, Adhortacja apostolska Evangelii gaudium o głoszeniu Ewangelii w dzisiejszym świecie, Watykan 2013.

Franciszek, Bez pracy nie ma godności. Przemówienie podczas spotkania ze światem pracy na Largo Carlo Felice, L'ORpol 2013, nr 11, s. 21-23.

Franciszek, Dzieci i dziadkowie sa nadzieją ludu. Przemówienie do członków włoskiego Ruchu na rzecz Życia, L'ORpol 2014, nr 5, s. 27-28.

Franciszek, Ewangelia spotkania młodych i starszych. Homilia podczas Mszy św. dla ludzi w podesztym wieku, L'ORpol 2014, nr 10, s. 40-41.

Franciszek, Głoście Ewangelię, jeśli trzeba, także słowami! Spotkanie z młodzieża na placu przed bazylika Matki Bożej Anielskiej, L'ORpol 2013, nr 11, s. 16-19.

Franciszek, Każdego dnia budujemy pokój w rodzinie. Rozważanie Papieża podczas spotkania modlitewnego z rodzinami, „L'ORpol 2013, nr 12, s. 10-12.

Franciszek, Kościót wychodzi naprzeciw wszystkim. Czuwanie modlitewne z okazji dnia ruchów, nowych wspólnot i stowarzyszeń kościelnych, L’ORpol 2013, nr 7, s. 16-20.

Franciszek, List Papieża Franciszka do rodzin, L'ORpol 2014, nr 3-4, s. 23-24.

Franciszek, Mitość cierpliwa, która rodzi radość. Homilia Ojca Świętego podczas Mszy św. dla rodzin, L'ORpol 2013, nr 12, s. 12-13.

Franciszek, Młodzi muszq mieć skrzydła i korzenie. Wideokonferencja z uczniami z pięciu krajów świata, L'ORpol 2014, nr 10, s. 24-26.

Franciszek, Najcięższa choroba, na jaka sq narażone osoby starsze, jest opuszczenie. Przestanie z okazji 20-lecia Papieskiej Akademii Pro Vita, L’ORpol 2014, nr 3-4, s. 20-21.

Franciszek, Naród odważny i silny. Audiencja generalna w Watykanie po podróży do Albanii, L'ORpol 2014, nr 10, s. 21-22.

Franciszek, Niech was będzie stychać. Spotkanie z młodzieżą argentyńska, L'ORpol 2013, nr 8-9, s. 8-9.

Franciszek, Nikogo nie wolno odrzucać. Wizyta w faweli Varginha, L'ORpol 2013, nr 8-9, s. 6-7.

Franciszek, Pamięć o przeszłości i przyszłości. Przemówienie podczas spotkania z ludźmi starszymi na placu św. Piotra, L'ORpol 2014, nr 10, s. 39-40.

Franciszek, Panie daj nam zaznać świętego upojenia. Dialog Papieża z kapłanami, młodzieża, rodzinami i osobami niepetnosprawnymi, L'ORpol 2014, nr 7, s. 28.

Franciszek, Prawdziwa rewolucja jest współczucie. Przemówienie do wspólnoty św. Idziego, L'ORpol 2014, nr 7, s. 18-20.

Franciszek, Prośmy Maryję o opiekę nad osobami starszymi. Stowa przed modlitwa „Aniot Pański”, L'ORpol 2014, nr 10, s. 42. 
Franciszek, Przestrzenie godności i wolności. Spotkanie z uczestnikami międzynarodowej konferencji Papieskiej Rady ds. Duszpasterstwa Slużby Zdrowia i Chorych, L'ORpol 2014, nr 1, s. 30-31.

Franciszek, Równość w zróżnicowaniu. Przesłanie wideo do uczestników III Festiwalu Nauki Społecznej Kościoła, L'ORpol 2014, nr 1, s. 29-30.

Franciszek, Skażeni przez kulturę odrzucenia, L’ORpol 2013, nr 8-9, s. 48-49.

Franciszek, Solidarność między pokoleniami. Przesłanie z okazji 47. Tygodnia Społecznego Katolików Włoskich, L'ORpol 2013, nr 11, s. 32-34.

Franciszek, Trzeba budować porozumienie wychowawcze, L'ORpol 2014, nr 10, s. 23-24.

Franciszek, $W$ rodzinie uczymy się kochać i bronić życia. Audiencja dla uczestników zgromadzenia plenarnego Papieskiej Rady ds. Rodziny, L'ORpol 2013, nr 12, s. 27-29.

Jan Paweł II, Adhortacja apostolska Familiaris consortio, Watykan 1981.

Jan Paweł II, Bo tu jest twoje życie i dtugie trwanie twego pobytu na ziemi. Orędzie Ojca Świętego na Wielki Post 2005 r., L’ORpol 2005, nr 3, s. 5-7.

Jan Paweł II, Cenna rola osób starszych w Kościele, L'ORpol 1994, nr 11, s. 38-39. Jan Paweł II, Chrystus przemienia cierpienie w źródło łaski $i$ życia. Orędzie na XI Światowy Dzień Chorego 11 lutego 2003 r., w: W trosce o życie. Wybrane dokumenty Stolicy Apostolskiej, red. J. Brusiło, Tarnów 2012, s. 397-400.

Jan Paweł II, Chrześcijański sens cierpienia i starości. W szpitalu św. Karola Boromeusza w Onitsha, w: Nauczanie papieskie, red. E. Weron, A. Jaroch, t. 5, cz. 1, Poznań 1993, s. 186-187.

Jan Paweł II, Człowiek chory zawsze zachowuje swa godność. Przemówienie do uczestników Międzynarodowego Kongresu Lekarzy Katolickich, w: W trosce o życie. Wybrane dokumenty Stolicy Apostolskiej, red. J. Brusiło, Tarnów 2012, s. 294-297.

Jan Paweł II, Człowieka nie można sprowadzić do przedmiotu. List do Michaela Camdessusa, Prezesa Tygodni Społecznych Francji, w: W trosce o życie. Wybrane dokumenty Stolicy Apostolskiej, red. J. Brusiło, Tarnów 2012, s. $182-185$.

Jan Paweł II, Dar dtugiego życia. Jubileusz Ludzi Starych, L'ORpol 2000, nr 1112, s. 13-14.

Jan Paweł II, Encyklika Evangelium vitae o wartości i nienaruszalności życia ludzkiego, Watykan 1995.

Jan Paweł II, Encyklika Laborem exercens o pracy ludzkiej, Watykan 1981.

Jan Paweł II, List do osób w podeszlym wieku, L’ORpol 1999, nr 12, s. 4-11. 
Jan Paweł II, Ludzie starsi w życiu społeczeństwa. List papieski do uczestników II Światowego Zgromadzenia poświęconego problemom starzenia się ludności, L'ORpol 2002, nr 6, s. 8-9.

Jan Paweł II, Medycyna a prawa człowieka. Przemówienie na Jubileusz Lekarzy Katolickich, w: W trosce o życie. Wybrane dokumenty Stolicy Apostolskiej, red. J. Brusiło, Tarnów 2012, s. 256-258.

Jan Paweł II, Misja papieża jest obrona praw człowieka. Przemówienie z okazji uroczystości nadania doktoratu honoris causa Uniwersytetu La Sapienza, w: W trosce o życie. Wybrane dokumenty Stolicy Apostolskiej, red. J. Brusiło, Tarnów 2012, s. 280-284.

Jan Paweł II, Nie dajcie się zwyciężać złu, ale zło dobrem zwyciężajcie. Spotkanie czterech pokoleń na stadionie Azteków, L’ORpol 1999, nr 4, s. 27-29.

Jan Paweł II, Ochrona zdrowia a społeczeństwo. Przemówienie do uczestników Kongresu Papieskiej Rady ds. Duszpasterstwa Stużby Zdrowia, w: W trosce o życie. Wybrane dokumenty Stolicy Apostolskiej, red. J. Brusiło, Tarnów 2012, s. 264-266.

Jan Paweł II, Orędzie do światowego zebrania poświęconego sprawie starzenia się ludności, w: Nauczanie papieskie, red. E. Weron, A. Jaroch, t. 5, cz. 2, Poznań 1996, s. 222-226.

Jan Paweł II, Pochylmy głowy przed ludźmi starymi. Anioł Pański, w: Nauczanie papieskie, red. E. Weron, A. Jaroch, t. 5, cz. 1, Poznań 1993, s. 9.

Jan Paweł II, Poparcie roli osób starszych $w$ rodzinie i społeczeństwie, w: Nauczanie papieskie, red. E. Weron, A. Jaroch, t. 5, cz. 1, Poznań 1993, s. 612-614.

Jan Paweł II, Posynodalna adhortacja apostolska Christifideles laici o powołaniu i misji świeckich w Kościele i świecie dwadzieścia lat po Soborze Watykańskim II, Watykan 1988.

Jan Paweł II, Skierujmy nasze myśli ku najstarszym, w: Nauczanie papieskie, red. E. Weron, A. Jaroch, t. 1, Poznań-Warszawa 1987, s. 210-211.

Jan Paweł II, Starzec nich będzie biegunem ukierunkowania dla młodych pokoleń. Do starców z diecezji rzymskiej, w: Nauczanie papieskie, red. E. Weron, A. Jaroch, t. 5, cz. 2, Poznań 1996, s. 961-963.

Jan Paweł II, Szczególna misja starszych $w$ życiu rodziny ludzkiej. Do uczestników międzynarodowego forum poświęconego aktywności ludzi starych, w: Nauczanie papieskie, red. E. Weron, A. Jaroch, t. 3, cz. 2, Poznań-Warszawa 1986, s. 291-293.

Jan Paweł II, Środki przekazu społecznego a problem ludzi starszych. Orędzie na Światowy Dzień Środków Przekazu Społecznego, w: Nauczanie papieskie, red.

E. Weron, A. Jaroch, t. 5, cz. 1, Poznań 1993, s. 668-671. 
Jan Paweł II, Towarzyszyć choremu aż do końca. Przemówienie do uczestników konferencji Papieskiej Rady ds. Duszpasterstwa Stużby Zdrowia, w: W trosce o życie. Wybrane dokumenty Stolicy Apostolskiej, red. J. Brusiło, Tarnów 2012, s. 298-300.

Jan Paweł II, $W$ doświadczeniach starości łaczcie się z Chrystusem na krzyżu.

Spotkanie z ludźmi starymi w katedrze w Monachium, w: Nauczanie papieskie, red. E. Weron, A. Jaroch, t. 3, cz. 2, Poznań-Warszawa 1986, s. 699-704.

Jan Paweł II, W obronie życia i zdrowia każdej osoby ludzkiej. Przemówienie do członków Papieskiej Akademii Pro Vita, w: W trosce o życie. Wybrane dokumenty Stolicy Apostolskiej, red. J. Brusiło, Tarnów 2012, s. 208-211.

Jan Paweł II, Wielkość cywilizacji mierzy się postawa wobec osób starszych.

Przemówienie do Ruchu Emerytów i Starców, w: Nauczanie papieskie, red.

E. Weron, A. Jaroch, t. 5, cz. 1, Poznań 1993, s. 774-776.

Papieska Rada ds. Świeckich, Godność i posłannictwo ludzi starszych w Kościele i świecie, w: W trosce o życie, red. J. Brusiło, Tarnów 2012, t. 2, s. 499-516.

Pikuła N., Etos starości w aspekcie społecznym. Gerontologia dla pracowników socjalnych, Wydawnictwo WAM, Kraków 2011.

„Relatio synodi" - Wezwania duszpasterskie zwiazane z rodzina w kontekście ewangelizacji, L'ORpol 2014, nr 11, s. 8-18.

\section{Fr Roman Ceglarek: The place and the role of the elderly people in family in papal teaching in the twenty-first century}

In the twenty-first century in Francis', Benedict XVI and John Paul II teaching it is obvious that they desire to restore the respect towards the elderly people in family and estimate their role as well as their place in it. Popes want the elderly people to be respected and cared with proper concern. Popes prove that the elderly people are not only the beneficiaries but also the donors in family. Therefore, the elderly people are precious support to the young generations, as they pass the young people wisdom as well as experience of life, the history of the family and the nation, finally, they become the witnesses of faith. According to the aforementioned popes, the respect towards the elderly people, was some kind of determinant of humanism in the past. Undoubtedly, it also should be such now, in order to bear witness the quality of the twenty-first century civilization positively.

Key words: the elderly people, family, popes: John Paul II, Benedict XVI, Francis. 